\title{
In Vitro Characterization of Immune-Related Properties of Human Fetal Bone Cells for Potential Tissue Engineering Applications
}

\author{
Marc-Olivier Montjovent, Ph.D., ${ }^{1}$ Chiara Bocelli-Tyndall, Ph.D., ${ }^{2,3}$ Corinne Scaletta, B.S., \\ Arnaud Scherberich, Ph.D., ${ }^{3}$ Silke Mark, Ph.D., ${ }^{5}$ Ivan Martin, Ph.D., ${ }^{3}$ \\ Lee Ann Applegate, Ph.D., ${ }^{4}$ and Dominique P. Pioletti, Ph.D. ${ }^{1}$
}

We describe herein some immunological properties of human fetal bone cells recently tested for bone tissueengineering applications. Adult mesenchymal stem cells (MSCs) and osteoblasts were included in the study for comparison. Surface markers involved in bone metabolism and immune recognition were analyzed using flow cytometry before and after differentiation or treatment with cytokines. Immunomodulatory properties were studied on activated peripheral blood mononuclear cells (PBMCs). The immuno-profile of fetal bone cells was further investigated at the gene expression level. Fetal bone cells and adult MSCs were positive for Stro-1, alkaline phosphatase, CD10, CD44, CD54, and $\beta 2$-microglobulin, but human leukocyte antigen (HLA)-I and CD80 were less present than on adult osteoblasts. All cells were negative for HLA-II. Treatment with recombinant human interferon gamma increased the presence of HLA-I in adult cells much more than in fetal cells. In the presence of activated PBMCs, fetal cells had antiproliferative effects, although with patterns not always comparable with those of adult MSCs and osteoblasts. Because of the immunological profile, and with their more-differentiated phenotype than of stem cells, fetal bone cells present an interesting potential for allogeneic cell source in tissue-engineering applications.

\section{Introduction}

$\mathbf{I}_{\mathrm{r}}^{\mathrm{N}}$ N THE AREA OF orthopedic medicine, cell-based approaches include bone marrow preparations, ${ }^{1}$ mesenchymal stem cells (MSCs), ${ }^{2,3}$ a hybrid approach of stem cells with gene therapy, ${ }^{4}$ and osteoprogenitor cells. ${ }^{5}$

The use of bone marrow-derived MSCs (BM-MSCs) seems also to represent a promising approach. Local delivery of purified MSCs was used for spine fusion, ${ }^{6}$ segmental bone defects, ${ }^{2}$ and craniotomy defects. ${ }^{3}$ Similar approaches have also been described for the repair of defects in articular cartilage ${ }^{7,8}$ and tendon. ${ }^{9}$ However, there are several limitations associated with the use of BM-MSCs for bone regeneration. First, the scarcity of osteoprogenitors in mature bone marrow, especially from elderly individuals, has been described clinically. ${ }^{10-13}$ Furthermore, an age dependency was detected such that the use of bone marrow cells from aged rats seeded on porous hydroxyapatite scaffolds implanted subcutaneously was associated with less ectopic bone formation than from younger donors. ${ }^{14}$ Additionally, although adult MSCs may differentiate into several lineages depending on the local extracellular signal, they are not committed to differentiation into the osteoblast lineage.

BM-MSCs have been considered to have unique immunologically privileged properties, ${ }^{15}$ but application occurred in heavily immunosuppressed recipients, and recent data in immunocompetent animals challenged their immunoprivilege. ${ }^{16}$ Donor-derived MSCs were immunogenic in an allogeneic host and stimulated donor graft rejection in a nonmyeloablative setting. However, BM-MSC immunomodulatory effects were verified by inhibiting T-cell allogeneic proliferation induced in mixed lymphocyte cultures or by non-specific mitogens. In general, fetal MSCs were shown to express lower levels of human leukocyte antigen (HLA) class I molecules than adult MSCs, ${ }^{17}$ indicating an immunoprivilege of fetal cells.

\footnotetext{
${ }^{1}$ Laboratory of Biomechanical Orthopedics, Center of Translational Biomechanics, Ecole Polytechnique Fédérale de Lausanne, Lausanne, Switzerland.

${ }^{2}$ Rheumatology Department, University Hospital, Basel, Switzerland.

${ }^{3}$ Departments of Surgery and Research, University Hospital, Basel, Switzerland.

${ }^{4}$ Orthopedic Cell Therapy Unit, Centre Hospitalier Universitaire Vaudois and University of Lausanne, Lausanne, Switzerland.

${ }^{5}$ Ludwig Institute for Cancer Research, Lausanne Branch, Epalinges, Switzerland.
} 
Stem cell populations with osteogenic potential have been identified in other mesenchymal tissues than bone marrow; skeletal muscle ${ }^{18,19}$ and fat ${ }^{20}$ may serve as alternative sources of precursor cells for bone regeneration. Alternatively to the reimplantation of MSCs, an osteoprogenitor cell line (OPC-1) has been established ${ }^{21}$ and used in combination with a porous carrier and recombinant human bone morphogenic protein2 , showing synergistic effects on osteoinduction in vivo. ${ }^{5}$

The use of human fetal bone cells for tissue engineering has recently been described. Fetal bone cells were shown to proliferate, differentiate, and finally to mineralize their extracellular matrix in vitro. ${ }^{22}$ Furthermore, they promoted new bone formation in vivo in immunocompetent rats. ${ }^{23}$ Because fetal bone cells have already engaged into the osteoblast lineage, they are easier to isolate than fetal MSCs, and a cell bank may be generated from only a few donors, overcoming the cell-sourcing problems associated with the use of MSCs. Fetal cells may be considered as a potential alternative to MSCs.

The aim of this study was to compare the immunogenicity of fetal bone cells in vitro with that of BM-MSCs and differentiated adult osteoblasts from the perspective of using them as an allogeneic cell source for bone tissue engineering. The expression of cell surface markers involved in immune recognition (HLA-I, HLA-II, CD80, CD86), bone metabolism (alkaline phosphatase (ALP), Stro-1, CD10, CD44), or both (CD54, $\beta 2$-microglobulin) was determined. Furthermore, the ability of fetal cells to regulate proliferation of activated peripheral blood mononuclear cells (PBMCs) was evaluated.

\section{Materials and Methods}

\section{Cell sources}

Human trabecular bone biopsies at femoral locations obtained from five adult men (median age 57.4; range 40-79) after orthopedic surgery and from five fetuses (median gestational age 14.8 weeks; range 13-16) after voluntary interruption of pregnancy were used. Biopsies were obtained in accordance with the Ethics Committee of University Hospital at Lausanne (Ethical Protocol 51/01). Bone samples were mechanically dissociated with a scalpel blade and transferred to $10-\mathrm{cm}$ culture-grade plates, where cell outgrowth was seen within 1 to 5 days for fetal and 10 to 12 days for adult tissue under normal culture conditions (Dulbecco's modified Eagle medium (DMEM; Invitrogen, Carlsbad, CA), $10 \%$ fetal calf serum (FCS; Sigma-Aldrich, St Louis, MO), $4 \mathrm{mM}$ L-glutamine (Invitrogen)). Adult BM-MSCs were isolated at the University Hospital Basel (Ethical Protocol rev 78/07) from the posterior iliac crest of the pelvic bone from five healthy volunteers (median age 44.7; range 34-52) as described previously. ${ }^{24}$ No age or sex exclusion criteria were fixed.

\section{Cell culture}

Bone cells were maintained in culture by passaging once a week and culturing at $37^{\circ} \mathrm{C}$ in a humidified, $5 \%$ carbon dioxide atmosphere in DMEM, 10\% FCS, and $4 \mathrm{mM}$ L-glutamine. Culture medium was changed twice a week. When close to confluence, the cells were detached using trypsinethylenediaminetetraacetic acid (EDTA; Invitrogen) and seeded at a density of 6,000 cells $/ \mathrm{cm}^{2}$ in T80 flasks. For the characterization of bone cells using a fluorescence-activated cell sorter (FACS), cytokines and osteogenic factors were tested as follows: $100 \mathrm{U} / \mathrm{mL}$ of recombinant human interferon gamma (rhIFN- $\gamma$; exposition of 7 days, Sigma-Aldrich); $500 \mathrm{U} / \mathrm{mL}$ of recombinant human tumor necrosis factor alpha $($ rhTNF- $\alpha$ ) (exposition of 7 days, Sigma-Aldrich); $100 \mathrm{U} / \mathrm{mL}$ of rhIFN- $\gamma$ and $500 \mathrm{U} / \mathrm{mL}$ of rhTNF- $\alpha$ (exposition of 7 days); $50 \mu \mathrm{g} / \mathrm{mL}$ of ascorbic acid, $1 \mathrm{mM}$ of $\beta$-glycerophosphate, $10 \mathrm{nM}$ of dexamethasone (differentiation mix, exposition of 14 days); differentiation mix and $100 \mathrm{U} / \mathrm{mL}$ of rhIFN- $\gamma$ (exposition of 14 days to the differentiation mix, together with rhIFN- $\gamma$ during the 7 last days); differentiation mix and $500 \mathrm{U} / \mathrm{mL}$ of rhTNF- $\alpha$ (exposition of 14 days to the differentiation mix, together with rhTNF- $\alpha$ during the last 7 days).

The effect of treatment with $100 \mathrm{U} / \mathrm{mL}$ of $\operatorname{rhIFN}-\gamma$, $500 \mathrm{U} / \mathrm{mL}$ of rhTNF- $\alpha$, or differentiation mix described above were further studied on fetal bone cells at the gene expression level using real-time polymerase chain reaction (PCR). Cells from passages 3 to 6 were used for all experimentations.

\section{BM-MSC culture conditions}

Cells were cultured in low-glucose DMEM or alphamodified minimum essential medium (Invitrogen) supplemented with $10 \%$ fetal bovine serum, as already described, without any additional growth factors. ${ }^{25}$ BM-MSCs were passaged up to a maximum of four times and were not stored frozen longer than 3 to 4 months before use in culture.

\section{Flow cytometric cell characterization}

Cells were seeded at a density of 6,000 cells $/ \mathrm{cm}^{2}$ in T80 flasks, and treatments were started $24 \mathrm{~h}$ later, with culture medium changed every second day. Osteoblastic cells were detached using a solution of $40 \%$ EDTA, washed, and fixed for $30 \mathrm{~min}$ in ice-cold $4 \%$ formaldehyde. After fixation, cells were washed and suspended at $1 \times 10^{6}$ cells $/ \mathrm{mL}$ in PBS with $3 \%$ FCS.

Aliquots of $100 \mu \mathrm{L}$ of the cell suspensions were incubated for $60 \mathrm{~min}$ in the dark at $4{ }^{\circ} \mathrm{C}$ with the appropriate monoclonal antibody. For this study, we used phycoerythrin (PE)conjugated antibodies against CD10; HLA-A, -B, and -C (Becton Dickinson Biosciences, Franklin Lakes, NJ); CD14; CD86 (R\&D Systems, Minneapolis, MN); and fluorescein isothiocyanate (FITC)- conjugated antibodies against CD54, CD80 (R\&D Systems), HLA-DR, -DP, and -DQ, and $32-$ microglobulin (Becton Dickinson Biosciences). Primary specific antibodies against CD34 (Zymed Laboratories Inc., South San Francisco, CA), CD44, CD45, and ALP (R\&D Systems) were detected using PE-conjugated goat anti-mouse immunoglobulin (Ig)G (1, 2a, 2b, 3) (Jackson ImmunoResearch, West Grove, PA), whereas Stro-1 (R\&D Systems) was detected using FITC-conjugated goat anti-mouse IgM (Jackson ImmunoResearch). Nonspecific fluorescence was determined using equal aliquots of cells. Each fluorescence analysis included appropriate PE- and FITC-conjugated negative isotype controls. A FACSCalibur flow cytometer (Becton Dickinson Biosciences) was used for analysis of fluorescent cells based on a reading of 5,000 gated cells per sample.

Percentage of positive cells was calculated upon substraction of the respective control. Up to $5 \%$ of positive cells, cells were not considered to express the investigated protein. 
In all experiments, a constant setting of the FACS was maintained (gain, amplifier, and photomultiplier voltage).

\section{RNA isolation and purification}

RNA isolation and purification procedures were performed using Nucleospin RNA II columns (Macherey-Nagel, Düren, Germany). RNA was eluted in $60 \mu \mathrm{L}$ of RNase-free water and stored at $-80^{\circ} \mathrm{C}$ until experimentation.

\section{First-strand synthesis}

For each sample, $1 \mu \mathrm{g}$ of total RNA was reverse-transcribed using the Taqman Universal PCR reagents with random hexamers (Applied Biosystems, Foster City, CA). Reaction volumes were fixed at $50 \mu \mathrm{L}$. The ABI Prism 7700 (Applied Biosystems) was programmed as following: $25^{\circ} \mathrm{C}$ $10 \mathrm{~min}, 48^{\circ} \mathrm{C} 30 \mathrm{~min}, 95^{\circ} \mathrm{C} 5 \mathrm{~min}$.

\section{Gene expression}

The samples were assessed for gene expression using the TaqMan Low-Density Arrays Immune Panel (Applied Biosystems). The list of targets and endogenous controls can be downloaded from https://products.appliedbiosystems.com. The equivalent of $2.2 \mathrm{ng}$ of total RNA was loaded into each of the 384 wells. Amplifications were monitored using the ABI Prism 7900 (Applied-Biosystems). Thermal cycle conditions were: $50^{\circ} \mathrm{C} 2 \mathrm{~min}$ and $95^{\circ} \mathrm{C} 10 \mathrm{~min}$ and then 50 cycles at $95^{\circ} \mathrm{C}$ $15 \mathrm{sec}$ and $60^{\circ} \mathrm{C} 1 \mathrm{~min}$. Because of statistical fluctuations observed with rare copies of messenger RNAs, the cycle number at the threshold level of log-based fluorescence (CT) was arbitrarily fixed to 30 to distinguish genes that are constitutively expressed from genes which are not expressed. Measurements were performed in quadruplicate for each gene of interest and for the five different fetal donors. Glyceraldehyde-3-phosphate dehydrogenase (GAPDH) primers and probes were used as internal controls. Data were analyzed using SDS Software v2.2 (Applied Biosystems). Relative gene expressions were analyzed with the $2^{-\Delta \Delta C T}$ method. ${ }^{26}$ Normalized to GAPDH, each gene expression was compared with the \%CT calibrator value from the untreated group. For each gene, results were expressed as the relative quantity (RQ) with the range determined by evaluating the expression: $2^{-\Delta \Delta C T}$, with $\Delta \Delta \mathrm{CT}+\mathrm{s}$ and $\Delta \Delta \mathrm{CT}-\mathrm{s}$, where $\mathrm{s}$ is the standard deviation of the $\Delta \Delta \mathrm{CT}$ value. Gene expression inductions due to cytokines were classified as follows: + for $1<\mathrm{RQ} \leq 10$; + for $10<\mathrm{RQ} \leq 100$; and +++ for $\mathrm{RQ}>100$. The mean RQ values of five donors were included.

\section{In vitro immunomodulatory properties of bone cells and adult BM-MSCs on actively proliferating PBMCs}

The proliferation of PBMCs from healthy donors in the presence of bone cells was performed in 96-well plates following a method described elsewhere. ${ }^{25}$ Bone cells were irradiated to ensure that incorporation of hydrogen $(3 \mathrm{H})$ occurred only in PBMCs. Previous results indicated that active cell proliferation is not required to induce the reported antiproliferative effect, nor is irradiation responsible for such antiproliferative effect. Briefly, bone cells were irradiated (30 Gy); seeded at dilutions of $0.4,2,10$, or $50 \times 10^{3}$ cells per well; and allowed to attach for at least $1 \mathrm{~h}$ at $37^{\circ} \mathrm{C}$ before PBMCs isolated from healthy donors using density gradient centrifugation (Lymphoprep, Axis-Shield PoC AS, Oslo, Norway) were added. PBMCs $\left(10^{5}\right.$ cells per well) in RPMI 1640 medium supplemented with $5 \%$ pooled human serum were added with or without the combination of anti-CD3e monoclonal antibody (anti-CD3 $\varepsilon \mathrm{mAb}, 0.5 \mu \mathrm{g} / \mathrm{mL}$, gift from Antonio Lanzavecchia, Bellinzona, Switzerland) and anti-CD28 monoclonal antibody (anti-CD28 mAb, $1 \mu \mathrm{g} / \mathrm{mL}$, Becton Dickinson Biosciences). The plates were incubated at $37^{\circ} \mathrm{C}$ for $48 \mathrm{~h}$, then pulsed for $18 \mathrm{~h}$ with $1 \mu \mathrm{Ci} /$ well ${ }^{3} \mathrm{H}$ thymidine (GE Healthcare, Little Chalfont, United Kingdom) and harvested and the ${ }^{3} \mathrm{H}$ cpm counted. Each condition was tested in triplicate.

\section{Statistical analyses}

For each cell type, five different donors were tested in triplicate. For the FACS analysis, a representative value from each donor was used to calculate mean values and standard deviations (SDs) for fetal cells, adult MSCs and osteoblasts. The Student $t$-test was applied to assess whether the means of two groups were statistically different from each other. A value of $p<0.05$ was taken as a significant difference (otherwise noted NS).

\section{Results}

\section{Flow cytometric characterization of bone cells}

The characterization of bone cells for the presence of selected surface markers is summarized in Table 1. Fetal bone cells exhibited a strong expression of Stro-1 $(91.6 \pm 8.1 \%)$ and ALP $(82.4 \pm 7.4 \%)$. These cells were also positive for CD10, CD44, CD54, and the HLA-I-associated $\beta 2$-microglobulin. Additionally, lower expressions of HLA-I and CD80 were observed than with adult osteoblast cells $(-88 \%, p<0.05$ and $-100 \% p<0.001$, respectively).

Adult MSCs showed an intermediate pattern; they were also positive for Stro-1 (90.2 $\pm 4.3 \%)$ and ALP (71.6 $\pm 19.3 \%)$, but HLA-I and CD80 were less present than on adult osteoblasts $(-27 \% \mathrm{~ns}$, and $-75 \%, p<0.05$, respectively). All cells were negative for HLA-II. Moreover, the absence of CD14, CD34, and CD45 antigens, verified for all donors, showed that there was no contaminating hematopoietic stem cells at the passages considered.

\section{Effects of rhIFN- $\gamma$ and rhTNF- $\alpha$ cytokines alone or in combination on HLA-I, HLA-II, and CD54 cell-surface proteins}

The effects of rhIFN- $\gamma$ and rhTNF- $\alpha$ cytokines on selected surface markers of bone cells are summarized in Table 2. After treatment with rhIFN- $\gamma$, the number of fetal bone cells expressing HLA-II (91-fold, $p<0.001)$ and CD54 increased (0.1-fold, $p<0.01)$, with a dramatic augmentation of mean fluorescence intensities (data not shown), whereas the mean fluorescence intensity of HLA-I was only slightly affected (data not shown). Treatment with rhTNF- $\alpha$ had only an influence on the percentage of HLA-I- $(3.1$-fold, $p<0.001)$ and CD54-positive cells (0.1-fold $p<0.01)$, with no effect on HLA-II. Concomitant treatment with $\operatorname{rhIFN}-\gamma$ and $\operatorname{rhTNF}-\alpha$ led to a synergistic effect on CD54 in terms of mean fluorescence intensity (data not shown). These observations were also verified with adult MSCs and adult osteoblasts. rhIFN- $\gamma$ increased the presence of HLA-I positive adult cells tested (1.6-fold, 


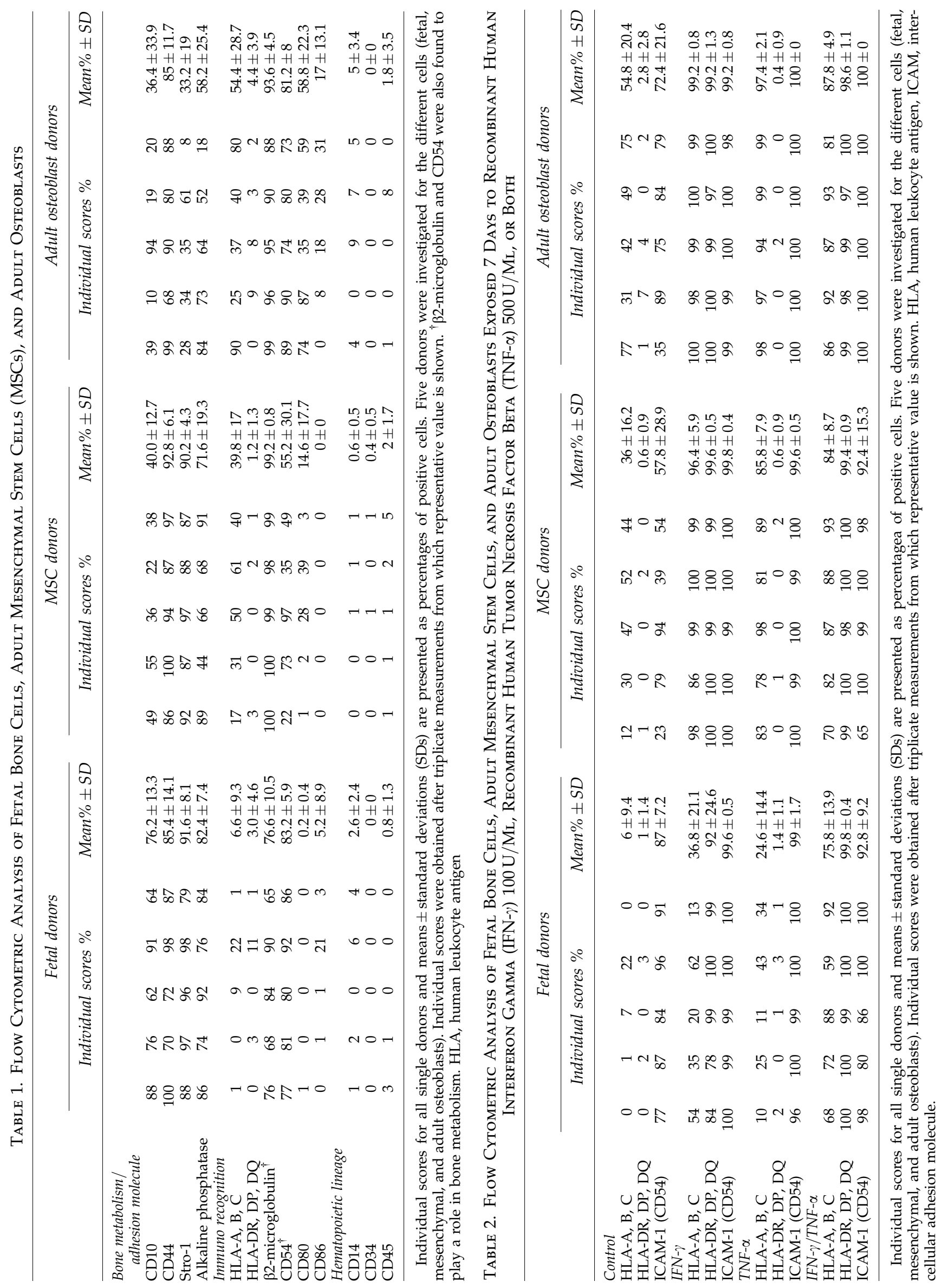


$p<0.001$ for BM-MSCs and 0.8-fold, $p=0.001$ for adult osteoblasts). The changes observed in terms of mean fluorescence intensities were higher with adult cells than with fetal cells (data not shown). Treatment of differentiation had no influence on HLA-I, HLA-II, and CD54 and did not change the effect of rhIFN- $\gamma$ or rhTNF- $\alpha$ on these surface markers for the different bone cells considered here (data not shown).

\section{Gene expression}

The immune profile of fetal bone cells was investigated using quantitative real-time PCR. The results of the genes that are discussed hereafter are shown in Table 3. The expression profile of all analyzed genes is presented in supplementary materials and methods. Confirming reports on osteoblast cells, CD54, Nuclear factor of kappa light poly- peptide gene enhancer in B-cells 2 (NFKB2), Fas (CD95), transforming growth factor beta (TGF- $\beta$ ), vascular endothelial growth factor (VEGF)-A, endothelial (EDN)1, interleukin (IL)-6, IL-8, and monocyte chemotactic protein (MCP)-1 were found to be constitutively expressed. Cytokines that stimulate osteoclast activity such as granulocyte monocyte colony stimulating factor, TNF- $\alpha$, and IL-1 were not detected like HLA-DR, CD80, CD86, IFN- $\gamma$, FasL (CD95L), IL-2, IL-4, IL10 , and IL-18 messenger RNAs (mRNAs). Confirming the observations made using flow cytometry, rhIFN- $\gamma$ strongly increased the expression of HLA-DR and CD54 genes in fetal bone cells. Relative quantities (RQs) were 10,495 $\pm 6,309$ $(p<0.01)$ and $17.0 \pm 12.6(p<0.05)$, respectively. This cytokine had no effect on CD80 or CD86. Treatment with rhTNF- $\alpha$ upregulated CD54 expression (RQ 8.0 \pm 1.6 , $p<0.001)$, but had no effect on HLA-DR, CD80, or CD86.

Table 3. Immune Profile of Fetal Bone Cells (Selection of Genes)

\begin{tabular}{|c|c|c|c|c|}
\hline \multirow[b]{2}{*}{ Refseq Number } & \multirow[b]{2}{*}{ Gene name } & \multirow[b]{2}{*}{ Function } & \multicolumn{2}{|c|}{ Inducible with: } \\
\hline & & & $I F N-\gamma$ & $T N F-\alpha$ \\
\hline \multicolumn{5}{|c|}{ Genes Constitutively Expressed } \\
\hline NM_002982 & CCL2 & Chemokine C-C ligand 2 (MCP-1) & & + \\
\hline NM_001397 & ECE1 & Endothelin converting enzyme 1 & & \\
\hline NM_000201 & ICAM1 & $\begin{array}{l}\text { Intercellular adhesion molecule } 1 \\
\text { (CD54), human rhinovirus receptor }\end{array}$ & ++ & + \\
\hline AF080158 & IKBKB & $\begin{array}{l}\text { Inhibitor of kappa light polypeptide } \\
\text { gene enhancer in B-cells, protein kinase beta }\end{array}$ & & \\
\hline NM_000600 & IL6 & Interleukin 6 (interferon, beta 2) & & \\
\hline NM_000584 & IL8 & Interleukin 8 & & ++ \\
\hline NM_002502 & NFKB2 & $\begin{array}{l}\text { Nuclear factor of kappa light polypetide } \\
\text { enhancer in B-cells } 2 \text { (p49/p100) }\end{array}$ & & + \\
\hline NM_000660 & TGFB1 & Transforming growth factor b1 & & \\
\hline NM_000043 & TNFRSF6 & $\begin{array}{l}\text { Tumor necrosis factor receptor superfamily, } \\
\text { member } 6 \text { (Fas, CD95) }\end{array}$ & + & \\
\hline NM_003376 & VEGFA & Vascular endothelial growth factor A & & \\
\hline NM_001955 & EDN1 & Endothelin & & \\
\hline \multicolumn{5}{|c|}{ Genes Not Constitutively Expressed } \\
\hline NM_005191 & CD80 & $\begin{array}{l}\text { CD80 antigen (CD28 antigen ligand 1, } \\
\text { B7-1 antigen) }\end{array}$ & & \\
\hline NM_006889 & CD86 & $\begin{array}{l}\text { CD86 antigen (CD28 antigen ligand 2, } \\
\text { B7-2 antigen) }\end{array}$ & & \\
\hline NM_000758 & CSF2 & $\begin{array}{l}\text { Colony stimulating factor } 2 \\
\quad \text { (granulocyte-macrophage) }\end{array}$ & & \\
\hline NM_019111 & HLA-DRA & $\begin{array}{l}\text { Major histocompatibility complex, } \\
\text { class II, DR alpha }\end{array}$ & +++ & \\
\hline NM_002124 & HLA-DRB1 & $\begin{array}{l}\text { Major histocompatibility complex, } \\
\text { class II, DR beta } 1\end{array}$ & & \\
\hline NM_012092 & ICOS & Inducible T-cell co-stimulator & & \\
\hline NM_000619 & IFNG & Interferon gamma & & \\
\hline NM_000572 & IL10 & Interleukin 10 & & \\
\hline NM_001562 & IL18 & $\begin{array}{l}\text { Interleukin } 18 \\
\quad \text { (interferon-gamma-inducing factor) }\end{array}$ & & \\
\hline NM_000575 & IL1A & Interleukin 1 alpha & & + \\
\hline NM_000576 & IL1B & Interleukin 1 beta & & + \\
\hline NM_000586 & IL2 & Interleukin 2 & & \\
\hline NM_000589 & IL4 & Interleukin 4 & & \\
\hline NM_000625 & NOS2A & Nitric oxide synthase $2 \mathrm{~A}$ & +++ & \\
\hline NM_000594 & TNF & Tumor necrosis factor superfamily, member 2 & & \\
\hline NM_000639 & TNFSF6 & $\begin{array}{l}\text { Tumor necrosis factor (ligand) } \\
\text { superfamily, member } 6 \text { (FasL, CD95L) }\end{array}$ & & \\
\hline
\end{tabular}



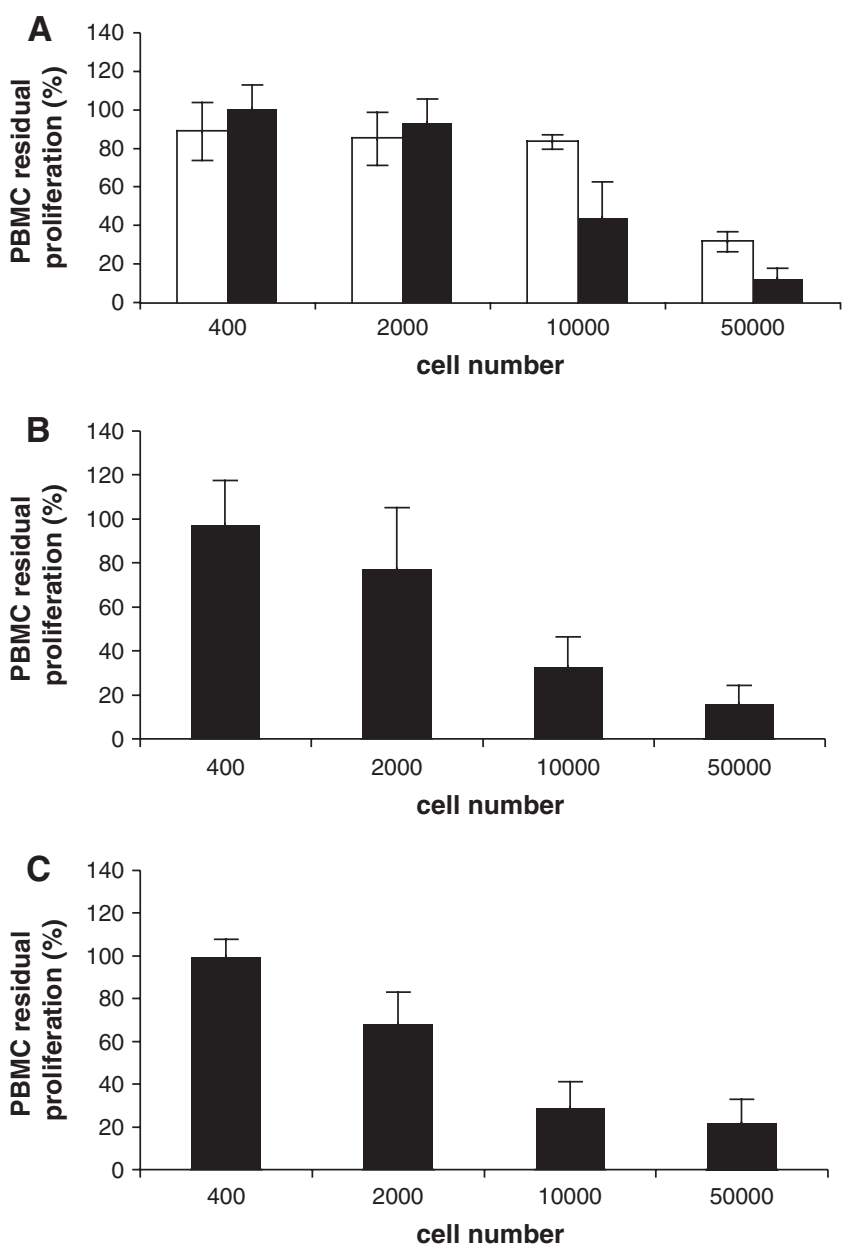

FIG. 1. Residual proliferation of anti-CD $3 \alpha / C D 28 \mathrm{mAbs}$ antibody-stimulated peripheral blood mononuclear cells (PBMCs) in the presence of increasing numbers of irradiated fetal bone cells (A), adult bone marrow mesenchymal cells (BM-MSCs) (B), and adult bone cells (C). The proliferation of 100,000 stimulated PBMCs was measured according to ${ }^{3} \mathrm{H}-$ thymidine uptake. Such proliferation in the presence of increasing numbers of each type of cell (residual proliferation) was normalized to that of the stimulated PBMCs alone. Each bar (y-axis) represents the percentage of residual proliferation of the PBMCs at each concentration $(50,000$ to 400$)$ of the co-cultured cells. All primary cell cultures, five samples for each type, had been expanded for three passages. In panel A, the white bar represents the PBMC residual proliferation of three different fetal primary cultures displaying a similar pattern; the black bar is related to the remaining two.

rhTNF- $\alpha$ upregulated NFKB2 (p100) (RQ 2.5 \pm 0.5 , $p<0.001)$. Differentiation did not change the gene expressions of HLA-DR, CD54, CD80, or CD86 on fetal bone cells (data not shown).

In vitro immunomodulatory properties of bone cells on previously stimulated and actively proliferating PBMCs

The in vitro antiproliferative effect of fetal and adult bone cells and adult BM-MSCs from five different donors each was tested on proliferating PBMCs stimulated with antiCD3 $\varepsilon$ CD28 mAbs as described in the Methods section. All cells were at the same culture passage (third). In two of the five fetal cell samples, the PBMC proliferation was fetal cellnumber dependent, with a significant reduction (56\%) at 10,000 cells ( $1: 10$ fetal cell-to-PBMC ratio). Further reduction (87\%) of PBMC proliferation was observed with 50,000 fetal cells (1:2 fetal cell-to-PBMC ratio) (Fig. $1 \mathrm{~A}$, dark bars). However, the remaining three fetal cell samples showed a different pattern of PBMC proliferation reduction; this was significant $(68 \%)$ only with the highest fetal cell concentration (1:2 fetal cell-to-PBMC ratio) while remaining basically ineffective up to and including the 1:10 fetal cell-to-PBMC ratio (Fig. 1A, white bars). This pattern was not observed in any of the BM-MSCs or adult bone cells (Fig. 1B, C), which displayed an antiproliferative effect similar to each other's and to those of the two fetal cells above.

An identical pattern of impaired antiproliferative effect was also observed with one sample of fetal skin cells (data not shown). The significance of this finding is under investigation, because there is no obvious stringent association with other cell characteristics. The antiproliferative property of the adult MSCs tested was independent of whether they were irradiated, and the PBMCs were not stimulated by stromal cells alone (data not shown).

\section{Discussion}

In this study, fetal bone cells were characterized and compared with adult BM-MSCs and adult bone cells for in vitro immunological properties. First, we demonstrated that fetal and adult bone cells share similar expression patterns for markers known to be involved in bone metabolism, such as Stro-1, ALP, CD10, the adhesion molecules CD44 and CD54, and $\beta 2$-microglobulin. Stro- $1+/$ ALP + bone marrow cells were found to represent a preosteoblastic stage of development, whereas Stro-1-/ALP + and Stro-1-/ALP- cells appeared to represent fully differentiated osteoblasts. ${ }^{27} \mathrm{We}$ observed that fetal bone cells and BM-MSCs are Stro$1+/ \mathrm{ALP}+$, whereas ALP + adult bone cells showed an intermediate pattern concerning Stro-1, indicating a moredifferentiated osteoblastic phenotype.

The presence of CD10 assessed on fetal and adult bone cells in this study was previously described on osteoblasts; its endopeptidase function could be involved in the process of bone formation. ${ }^{28}$

A strong and constitutive expression of CD10 and CD44 was described on cultured human osteoblasts in flow cytometry studies $^{29-31}$ and on human bone tissue sections using immunohistochemistry. ${ }^{32}$ Other authors described expression of CD44 antigen, a multifunctional adhesion molecule that binds to extracellular matrix molecules such as hyaluronate, $^{33}$ type I collagen, and fibronectin ${ }^{34}$ during the change from osteoblast to osteocyte. ${ }^{35}$ However, the presence of CD44 in osteoblastic cells at various maturational stages was assessed in rat fetal bone at the mRNA and protein levels. $^{36}$

The presence of CD54 on osteoblasts is well documented, ${ }^{30,37}$ and its upregulation on osteoblastic cells consecutive to CD44 stimulation by fragmented hyaluronan was shown to facilitate osteoclastogenesis. ${ }^{38,39}$ In accordance with our findings, TNF- $\alpha$ and IFN- $\gamma$ signal transduction pathways activate CD54. ${ }^{40}$ These cytokines act via nuclear factor kappa beta or signal transducers and activators of transcription proteins (STAT), respectively, and synergistically when 
present together. Two regions of the CD54 promoter mediating the cytokine responses were reported, and they were found to be necessary for synergism; thus, both transcription factor complexes function independently to increase the transcription initiation. ${ }^{41}$ TNF- $\alpha$ induces NFKB2 (p100) expression at the mRNA and protein levels in human monocytes, whereas IFN- $\gamma$ does not have such an effect. An increase in the transcription rate and mRNA stability was shown to mediate the observed induction of expression. ${ }^{42}$ We report in this study an induction of NFKB2 (p100) gene expression when fetal bone cells are in the presence of rTNF$\alpha$ but not with rIFN- $\gamma$. This could explain the strong upregulation of CD54 observed. The synergistic effect of rTNF- $\alpha$ and rIFN- $\gamma$ on CD54 was observed for fetal bone cells, adult MSCs and adult osteoblasts.

In addition to its cell surface expression where $\beta 2$ microglobulin is non-covalently associated with the heavy chain of HLA-I antigens, ${ }^{43}$ the production of $\beta 2$-microglobulin by human osteoblasts and its possible role as a local regulator of bone metabolism were described. ${ }^{44,45}$ Controversy still surrounds the exact role of $\beta 2$-microglobulin in normal and abnormal bone physiology due to the absence of an identified receptor and the disagreement concerning its mitogenic effect. $^{46}$

According to the results presented here, MSCs were recently described to express CD44 and HLA-I but not CD80, CD86, or HLA-II, ${ }^{47}$ whereas adult osteoblasts were shown to express CD54, CD80, CD86, and HLA-DR. ${ }^{29}$

Second, we investigated the interaction between fetal osteoblasts and lymphocytes. We report that fetal bone cells inhibited in vitro the proliferation of stimulated PBMCs, although with patterns not always comparable with those of adult mesenchymal and bone cells. The antiproliferative property observed on anti-CD3 8 - and anti-CD28-stimulated PBMCs did not depend on the active proliferation of fetal cells.

Non-induced fetal bone cells showed low and no expression of HLA-I and HLA-II, respectively. Moreover, the costimulatory molecules CD80 and CD86 displayed on cells involved in antigen presentation and $\mathrm{T}$ cell activation were poorly expressed on fetal bone cells. Fetal MSCs isolated from fetal liver at a median gestational age of 9 weeks (range 6-10 weeks) were shown to express a moderate level of HLA-I, whereas HLA-II was uniformly negative. ${ }^{48}$ Recently, bone marrow fetal MSCs isolated from older fetuses (23-24 weeks) were described to be HLA-I positive in more than $50 \%$ of the cells tested and HLA-II negative $(<10 \%) .{ }^{49}$ These observations, taken together with ours, point out the importance of the organ and the gestational age. Donor variation could also not be excluded. For this study, fetuses of 13, 14,15 , and 16 weeks' gestational age were used. HLA-I antigens appear early in embryonic development, and HLA-II markers appear later, usually between the 20th and the 32nd weeks of gestation for humans. ${ }^{50}$

In mice, class I gene expression is detectable at the midsomite (10-day) stage but can be induced earlier by interferons, suggesting that interferon is the physiologic inducer of MHC expression. ${ }^{51}$ We observed the induction of HLA-I by $\mathrm{rINF}-\gamma$ and rTNF- $\alpha$ on fetal cells, MSCs, and adult bone cells, as previously demonstrated for MSCs isolated from bone marrow aspirates, ${ }^{52}$ whereas HLA-II was only upregulated by rINF- $\gamma$. This last observation was associated with a strong upregulation of HLA-DR gene expression, which is in accordance with previous studies on adult osteoblasts, ${ }^{53}$ dermal fibroblasts, ${ }^{54}$ synovial fibroblasts, ${ }^{55}$ and chondrocytes. ${ }^{56}$ Cytokine treatments did not affect costimulatory molecules CD80 and CD86, as already demonstrated for IFN- $\gamma$ on osteoblasts ${ }^{57}$ and MSCs. ${ }^{58}$ However, fetal MSCs exposed to IFN- $\gamma$ for 7 days, thus expressing HLA class I and II molecules, inhibit lymphocyte like with adult MSCs. ${ }^{48}$ Hence, despite the up-regulation of HLA-II alloantigens, other phenomena induced by IFN- $\gamma$ appear to amplify the antiproliferative effect that fetal MSCs exert on lymphocyte proliferation. Thus, MSCs do not escape alloreactivity and suppress lymphocyte alloreactivity merely because they lack HLA class II antigens. It has been reported that a soluble factor could lead to suppression of mixed lymphocyte culture proliferation ${ }^{58}$ and that TGF- $\beta$ and HGF secreted by MSCs could function synergically. ${ }^{59}$ We observed strong expression of TGF- $\beta$ in fetal bone cells.

In this study, adult osteoblasts were always HLA-I+, whereas HLA-II was weakly expressed ( 15\%). Expression of HLA-DR has been described on osteoblasts obtained after mandibular surgery $(13-54 \%)^{30}$ and HLA-DR + or HLADR- osteoblasts produced osteocalcin when stimulated with 1,25-di-hydroxyvitamin D3. ${ }^{53}$ It was suggested that HLAII + osteoblasts could play a role in local T lymphocyte activation. $^{30,57}$

Finally, we investigated for the first time immunological properties of human fetal osteoblasts at the gene expression level. We observed that TGF- $\beta$, VEGF-A, EDN1, IL-6, and MCP-1 are constitutively expressed. TGF- $\beta$ is mainly produced in bones, ${ }^{60,61}$ and fetal osteoblasts from rats and calves can synthesize and secrete TGF- $\beta$. It could function as an autocrine growth factor on these cells, with mitogenic properties. ${ }^{62}$ As mentioned above, TGF- $\beta$ could participate in the antiproliferative effect observed on blood cells, ${ }^{59}$ whereas VEGF-A and EDN1 might participate in the cross-talk between osteoblasts and endothelial cells during bone formation and remodeling. From the perspective of using fetal bone cells for tissue engineering, this could be of particular interest, because vascularization of the scaffold seeded with cells will be crucial for the repair process. Bone morphogenetic proteins stimulate angiogenesis through the production of VEGF-A by osteoblasts. ${ }^{63}$ Murine preosteoblasts express it in a differentiation-dependent fashion, and exogenous VEGF-A stimulated osteoblast differentiation, ${ }^{64}$ whereas EDN1 promoted osteoblastic proliferation and differentiation. ${ }^{65}$ The IL-6 gene expression is closely associated with the differentiation of mesenchymal cells to osteoblasts and was detected in sections of human developing osteophytes ${ }^{66}$ and in human osteoblasts in vitro. ${ }^{67}$ Production of IL-6 and IL-8 but not IL- 4 or TNF- $\alpha$ was observed in differentiated osteoblasts. ${ }^{68} \mathrm{MCP}-1$ is induced during inflammation and in developmentally regulated bone remodeling. ${ }^{69}$

We conclude that fetal bone cells share properties with adult BM-MSCs concerning surface markers involved in bone metabolism. Moreover, fetal bone cells and BM-MSCs do not present HLA-II or the co-stimulatory molecule CD80, on their cytoplasmic membrane, which play a role in immune recognition, even if the former was inducible with rIFN $-\gamma$. In the perspective of their use in tissue engineering, fetal bone cells could be selected for their osteogenic and immune-related properties. These, along with their 
previously reported rapid growth, ${ }^{22}$ ease of cell banking, and associated safety, ${ }^{70}$ may make them a viable alterative to adult BM-MSCs in bone tissue engineering.

\section{Acknowledgments}

This study was supported by grants from the Swiss National Science Foundation (FNRS $N^{\circ} 2100-066872.04 .01$ ) and by the Fondation Lémanique pour la Recherche sur le Tissu Osseux.

\section{Disclosure Statement}

No competing financial interests exist.

\section{References}

1. Connolly, J. F. Injectable bone marrow preparations to stimulate osteogenic repair. Clin Orthop Relat Res 8, 1995.

2. Quarto, R., Mastrogiacomo M., Cancedda R., Kutepov S. M., Mukhachev V., Lavroukov A., Kon E., and Marcacci M. Repair of large bone defects with the use of autologous bone marrow stromal cells. N Engl J Med 344, 385, 2001.

3. Krebsbach, P. H., Mankani M. H., Satomura K., Kuznetsov S. A., and Robey P. G. Repair of craniotomy defects using bone marrow stromal cells. Transplantation 66, 1272, 1998.

4. Dragoo, J. L., Lieberman J. R., Lee R. S., Deugarte D. A., Lee Y., Zuk P. A., Hedrick M. H., and Benhaim P. Tissueengineered bone from BMP-2-transduced stem cells derived from human fat. Plast Reconstr Surg 115, 1665, 2005.

5. Winn, S. R., Schmitt J. M., Buck D., Hu Y., Grainger D., and Hollinger J. O. Tissue-engineered bone biomimetic to regenerate calvarial critical-sized defects in athymic rats. I Biomed Mater Res 45, 414, 1999.

6. Muschler, G. F., Nitto H., Matsukura Y., Boehm C., Valdevit A., Kambic H., Davros W., Powell K., and Easley K. Spine fusion using cell matrix composites enriched in bone marrow- derived cells. Clin Orthop Relat Res 102, 2003.

7. Ponticiello, M. S., Schinagl R. M., Kadiyala S., and Barry F. P. Gelatin-based resorbable sponge as a carrier matrix for human mesenchymal stem cells in cartilage regeneration therapy. J Biomed Mater Res 52, 246, 2000.

8. Yan, H., and Yu C. Repair of full-thickness cartilage defects with cells of different origin in a rabbit model. Arthroscopy 23, 178, 2007.

9. Young, R. G., Butler D. L., Weber W., Caplan A. I., Gordon S. L., and Fink D. J. Use of mesenchymal stem cells in a collagen matrix for Achilles tendon repair. J Orthop Res 16, 406, 1998

10. Bertram, H., Mayer H., and Schliephake H. Effect of donor characteristics, technique of harvesting and in vitro processing on culturing of human marrow stroma cells for tissue engineered growth of bone. Clin Oral Implants Res 16, 524, 2005.

11. Muschler, G. F., Nitto H., Boehm C. A., and Easley K. A. Age- and gender-related changes in the cellularity of human bone marrow and the prevalence of osteoblastic progenitors. J Orthop Res 19, 117, 2001.

12. Muschler, G. F., Boehm C., and Easley K. Aspiration to obtain osteoblast progenitor cells from human bone marrow: the influence of aspiration volume. J Bone Joint Surg Am 79, 1699, 1997.

13. Pittenger, M. F., Mackay A. M., Beck S. C., Jaiswal R. K., Douglas R., Mosca J. D., Moorman M. A., Simonetti D. W.,
Craig S., and Marshak D. R. Multilineage potential of adult human mesenchymal stem cells. Science 284, 143, 1999.

14. Inoue, K., Ohgushi H., Yoshikawa T., Okumura M., Sempuku T., Tamai S., and Dohi Y. The effect of aging on bone formation in porous hydroxyapatite: biochemical and histological analysis. I Bone Miner Res 12, 989, 1997.

15. Le Blanc, K., and Ringden O. Immunobiology of human mesenchymal stem cells and future use in hematopoietic stem cell transplantation. Biol Blood Marrow Transplant 11, 321, 2005.

16. Nauta, A. J., Westerhuis G., Kruisselbrink A. B., Lurvink E. G., Willemze R., and Fibbe W. E. Donor-derived mesenchymal stem cells are immunogenic in an allogeneic host and stimulate donor graft rejection in a nonmyeloablative setting. Blood 108, 2114, 2006.

17. Le Blanc, K. Immunomodulatory effects of fetal and adult mesenchymal stem cells. Cytotherapy 5, 485, 2003.

18. Lee, J. Y., Qu-Petersen Z., Cao B., Kimura S., Jankowski R., Cummins J., Usas A., Gates C., Robbins P., Wernig A., and Huard J. Clonal isolation of muscle-derived cells capable of enhancing muscle regeneration and bone healing. I Cell Biol 150, 1085, 2000.

19. Bosch, P., Musgrave D. S., Lee J. Y., Cummins J., Shuler T., Ghivizzani T. C., Evans T., Robbins T. D., and Huard. Osteoprogenitor cells within skeletal muscle. I Orthop Res 18, 933, 2000.

20. Zuk, P. A., Zhu M., Mizuno H., Huang J., Futrell J. W., Katz A. J., Benhaim P., Lorenz H. P., and Hedrick M. H. Multilineage cells from human adipose tissue: implications for cell-based therapies. Tissue Eng 7, 211, 2001.

21. Winn, S. R., Randolph G., Uludag H., Wong S. C., Hair G. A., and Hollinger J. O. Establishing an immortalized human osteoprecursor cell line: OPC1. I Bone Miner Res 14, 1721, 1999.

22. Montjovent, M. O., Burri N., Mark S., Federici E., Scaletta C., Zambelli P. Y., Hohlfeld P., Leyvraz P. F., Applegate L. L., and Pioletti D. P. Fetal bone cells for tissue engineering. Bone 35, 1323, 2004.

23. Montjovent, M. O., Mark S., Mathieu L., Scaletta C., Scherberich A., Delabarde C., Zambelli P. Y., Bourban P. E., Applegate L. A., and Pioletti D. P. Human fetal bone cells associated with ceramic reinforced PLA scaffolds for tissue engineering. Bone 42, 554, 2008.

24. Frank, O., Heim M., Jakob M., Barbero A., Schafer D., Bendik I., Dick W., Heberer M., and Martin I. Real-time quantitative RT-PCR analysis of human bone marrow stromal cells during osteogenic differentiation in vitro. I Cell Biochem 85, 737, 2002.

25. Bocelli-Tyndall, C., Bracci L., Spagnoli G., Braccini A., Bouchenaki M., Ceredig R., Pistoia V., Martin I., and Tyndall A. Bone marrow mesenchymal stromal cells (BM-MSCs) from healthy donors and auto-immune disease patients reduce the proliferation of autologous- and allogeneic-stimulated lymphocytes in vitro. Rheumatology (Oxford) 46, 403, 2007.

26. Livak, K. J., and Schmittgen T. D. Analysis of relative gene expression data using real-time quantitative PCR and the 2(-Delta Delta C(T)) Method. Methods 25, 402, 2001.

27. Gronthos, S., Zannettino A. C., Graves S. E., Ohta S., Hay S. J., and Simmons P. J. Differential cell surface expression of the STRO-1 and alkaline phosphatase antigens on discrete developmental stages in primary cultures of human bone cells. J Bone Miner Res 14, 47, 1999.

28. Indig, F. E., Benayahu D., Fried A., Wientroub S., and Blumberg S. Neutral endopeptidase (EC 3.4.24.11) is highly 
expressed on osteoblastic cells and other marrow stromal cell types. Biochem Biophys Res Commun 172, 620, 1990.

29. Reyes-Botella, C., Montes M. J., Vallecillo-Capilla M. F., Olivares E. G., and Ruiz C. Antigenic phenotype of cultured human osteoblast-like cells. Cell Physiol Biochem 12, 359, 2002.

30. Reyes-Botella, C., Montes M. J., Vallecillo-Capilla M. F., Olivares E. G., and Ruiz C. Expression of molecules involved in antigen presentation and $\mathrm{T}$ cell activation (HLA-DR, CD80, CD86, CD44 and CD54) by cultured human osteoblasts. J Periodontol 71, 614, 2000.

31. Reyes-Botella, C., Montes M. J., Abadia-Molina A. C., Vallecillo-Capilla M. F., and Ruiz C. CD10 expression in cultured human osteoblast-like cells. Folia Biol (Praha) 45, 257, 1999.

32. Garcia-Martinez, O., Reyes-Botella C., Aguilera-Castillo O., Vallecillo-Capilla M. F., and Ruiz C. Antigenic profile of osteoblasts present in human bone tissue sections. Biosci Rep 26, 39, 2006.

33. Aruffo, A., Stamenkovic I., Melnick M., Underhill C. B., and Seed B. CD44 is the principal cell surface receptor for hyaluronate. Cell 61, 1303, 1990.

34. Carter, W. G., and Wayner E. A. Characterization of the class III collagen receptor, a phosphorylated, transmembrane glycoprotein expressed in nucleated human cells. J Biol Chem 263, 4193, 1988.

35. Nakamura, H., Kenmotsu S., Sakai H., and Ozawa H. Localization of $\mathrm{CD} 44$, the hyaluronate receptor, on the plasma membrane of osteocytes and osteoclasts in rat tibiae. Cell Tissue Res 280, 225, 1995.

36. Jamal, H. H., and Aubin J. E. CD44 expression in fetal rat bone: in vivo and in vitro analysis. Exp Cell Res 223, 467, 1996.

37. Tanaka, Y., Morimoto I., Nakano Y., Okada Y., Hirota S., Nomura S., Nakamura T., and Eto S. Osteoblasts are regulated by the cellular adhesion through ICAM-1 and VCAM1. J Bone Miner Res 10, 1462, 1995.

38. Tanaka, Y., Nakayamada S., and Okada Y. Osteoblasts and osteoclasts in bone remodeling and inflammation. Curr Drug Targets Inflamm Allergy 4, 325, 2005.

39. Fujii, Y., Fujii K., Nakano K., and Tanaka Y. Crosslinking of CD44 on human osteoblastic cells upregulates ICAM-1 and VCAM-1. FEBS Lett 539, 45, 2003.

40. Roebuck, K. A., and Finnegan A. Regulation of intercellular adhesion molecule-1 (CD54) gene expression. I Leukoc Biol 66, 876, 1999.

41. Jahnke, A., and Johnson J. P. Intercellular adhesion molecule 1 (ICAM-1) is synergistically activated by TNF-alpha and IFN-gamma responsive sites. Immunobiology 193, 305, 1995.

42. de Wit, H., Dokter W. H., Koopmans S. B., Lummen C., van der Leij M., Smit J. W., and Vellenga E. Regulation of p100 (NFKB2) expression in human monocytes in response to inflammatory mediators and lymphokines. Leukemia 12, 363, 1998.

43. Grey, H. M., Kubo R. T., Colon S. M., Poulik M. D., Cresswell P., Springer T., Turner M., and Strominger J. L. The small subunit of HL-A antigens is beta 2-microglobulin. J Exp Med 138, 1608, 1973.

44. Johansen, J. S., Williamson M. K., Rice J. S., and Price P. A. Identification of proteins secreted by human osteoblastic cells in culture. J Bone Miner Res 7, 501, 1992.

45. Evans, D. B., Thavarajah M., and Kanis J. A. Immunoreactivity and proliferative actions of beta 2 micro- globulin on human bone-derived cells in vitro. Biochem Biophys Res Commun 175, 795, 1991.

46. Balint, E., and Sprague S. M. Beta(2)-microglobulin and bone cell metabolism. Nephrol Dial Transplant 16, 1108, 2001.

47. Krampera, M., Cosmi L., Angeli R., Pasini A., Liotta F., Andreini A., Santarlasci V., Mazzinghi B., Pizzolo G., Vinante F., Romagnani P., Maggi E., Romagnani S., and Annunziato F. Role for interferon-gamma in the immunomodulatory activity of human bone marrow mesenchymal stem cells. Stem Cells 24, 386, 2006.

48. Gotherstrom, C., Ringden O., Tammik C., Zetterberg E., Westgren M., and Le Blanc K. Immunologic properties of human fetal mesenchymal stem cells. Am J Obstet Gynecol 190, 239, 2004.

49. Chen, X. L., Chen P., Jia Z. Q., Liu Y. N., Ma K. T., Zhang Y. Z., and Zhou C. Y. [HLA expression in human fetal bone marrow mesenchymal stem cells]. Beijing Da Xue Xue Bao 38, 597, 2006.

50. Natali, P. G., Russo C., and Ng A.-K. Tissue distribution of human Ia-like antigens. In: S. Ferrone and C. S. David, eds. Ia Antigens. Boca Raton, FL: CRC Press, 1982, p. 81-110.

51. Ozato, K., Wan Y. J., and Orrison B. M. Mouse major histocompatibility class I gene expression begins at midsomite stage and is inducible in earlier-stage embryos by interferon. Proc Natl Acad Sci U S A 82, 2427, 1985.

52. Majumdar, M. K., Keane-Moore M., Buyaner D., Hardy W. B., Moorman M. A., McIntosh K. R., and Mosca J. D. Characterization and functionality of cell surface molecules on human mesenchymal stem cells. J Biomed Sci 10, 228, 2003.

53. Skjodt, H., Hughes D. E., Dobson P. R., and Russell R. G. Constitutive and inducible expression of HLA class II determinants by human osteoblast-like cells in vitro. I Clin Invest 85, 1421, 1990.

54. Geppert, T. D., and Lipsky P. E. Antigen presentation by interferon-gamma-treated endothelial cells and fibroblasts: differential ability to function as antigen-presenting cells despite comparable Ia expression. J Immunol 135, 3750, 1985.

55. Amento, E. P., Bhan A. K., McCullagh K. G., and Krane S. M. Influences of gamma interferon on synovial fibroblast-like cells. Ia induction and inhibition of collagen synthesis. J Clin Invest 76, 837, 1985.

56. Jahn, B., Burmester G. R., Schmid H., Weseloh G., Rohwer P., and Kalden J. R. Changes in cell surface antigen expression on human articular chondrocytes induced by gammainterferon. Induction of Ia antigens. Arthritis Rheum 30, 64, 1987.

57. Stanley, K. T., VanDort C., Motyl C., Endres J., and Fox D. A. Immunocompetent properties of human osteoblasts: interactions with T lymphocytes. J Bone Miner Res 21, 29, 2006.

58. Klyushnenkova, E., Mosca J. D., Zernetkina V., Majumdar M. K., Beggs K. J., Simonetti D. W., Deans R. J., and McIntosh K. R. T cell responses to allogeneic human mesenchymal stem cells: immunogenicity, tolerance, and suppression. J Biomed Sci 12, 47, 2005.

59. Di Nicola, M., Carlo-Stella C., Magni M., Milanesi M., Longoni P. D., Matteucci P., Grisanti S., and Gianni A. M. Human bone marrow stromal cells suppress T-lymphocyte proliferation induced by cellular or nonspecific mitogenic stimuli. Blood 99, 3838, 2002.

60. Hauschka, P. V., Mavrakos A. E., Iafrati M. D., Doleman S. E., and Klagsbrun M. Growth factors in bone matrix. 
Isolation of multiple types by affinity chromatography on heparin- Sepharose. I Biol Chem 261, 12665, 1986.

61. Seyedin, S. M., Thomas T. C., Thompson A. Y., Rosen D. M., and Piez K. A. Purification and characterization of two cartilage-inducing factors from bovine demineralized bone. Proc Natl Acad Sci U S A 82, 2267, 1985.

62. Robey, P. G., Young M. F., Flanders K. C., Roche N. S., Kondaiah P., Reddi A. H., Termine J. D., Sporn M. B., and Roberts A. B. Osteoblasts synthesize and respond to transforming growth factor-type beta (TGF-beta) in vitro. I Cell Biol 105, 457, 1987.

63. Deckers, M. M., van Bezooijen R. L., van der Horst G., Hoogendam J., van Der Bent C., Papapoulos S. E., and Lowik C. W. Bone morphogenetic proteins stimulate angiogenesis through osteoblast-derived vascular endothelial growth factor A. Endocrinology 143, 1545, 2002.

64. Deckers, M. M., Karperien M., van der Bent C., Yamashita T., Papapoulos S. E., and Lowik C. W. Expression of vascular endothelial growth factors and their receptors during osteoblast differentiation. Endocrinology 141, 1667, 2000.

65. von Schroeder, H. P., Veillette C. J., Payandeh J., Qureshi A., and Heersche J. N. Endothelin-1 promotes osteoprogenitor proliferation and differentiation in fetal rat calvarial cell cultures. Bone 33, 673, 2003.

66. Dodds, R. A., Merry K., Littlewood A., and Gowen M. Expression of mRNA for IL1 beta, IL6 and TGF beta 1 in developing human bone and cartilage. J Histochem Cytochem 42, 733, 1994.

67. Littlewood, A. J., Russell J., Harvey G. R., Hughes D. E., Russell R. G., and Gowen M. The modulation of the ex- pression of IL-6 and its receptor in human osteoblasts in vitro. Endocrinology 129, 1513, 1991.

68. Chaudhary, L. R., Spelsberg T. C., and Riggs B. L. Production of various cytokines by normal human osteoblast-like cells in response to interleukin-1 beta and tumor necrosis factor-alpha: lack of regulation by 17 beta-estradiol. Endocrinology 130, 2528, 1992.

69. Volejnikova, S., Laskari M., Marks S. C., Jr., and Graves D. T. Monocyte recruitment and expression of monocyte chemoattractant protein-1 are developmentally regulated in remodeling bone in the mouse. Am J Pathol 150, 1711, 1997.

70. Quintin, A., Hirt-Buri N., Scaletta C., Schizas C., and Pioletti D.P. Consistency of fetal cell banks for research and clinical use. Cell Transplantation 16, 675, 2007.

Address correspondence to:

Dominique P. Pioletti, Ph.D.

Laboratory of Biomechanical Orthopedics

Center of Translational Biomechanics EPFL-CHUV-DAL

Station 15

Ecole Polytechnique Fédérale de Lausanne CH-1015 Lausanne

Switzerland

E-mail: dominique.pioletti@epfl.ch

Received: April 16, 2008

Accepted: October 7, 2008

Online Publication Date: January 13, 2009 